\title{
Beberapa Faktor yang Berhubungan dengan Episode Infeksi Saluran Pernapasan Akut pada Anak dengan Penyakit Jantung Bawaan
}

\author{
Rocky Wilar, J. M. Wantania
}

Latar belakang. Infeksi saluran pernapasan akut (ISPA) merupakan penyakit yang sering diderita oleh anak-anak. Gangguan hemodinamik pada penyakit jantung bawaan (PJB) dapat menyebabkan infeksi saluran pernapasan yang berulang. Banyak faktor risiko yang berhubungan dengan terjadinya ISPA.

Tujuan penelitian. Mengetahui episode dan lamanya ISPA pada anak dengan PJB dan faktor-faktor yang berhubungan dengan terjadinya ISPA tersebut.

Metoda. Jenis penelitian ini adalah studi longitudinal (prospektif), sejak 10 Nopember 2004 sampai 10 Juni 2005 pada 47 anak yang menderita PJB (29 tipe non sianotik dan 18 tipe sianotik) yang berusia 6 bulan sampai 12 tahun. Diagnosis PJB berdasarkan atas anamnesis, pemeriksaan fisik, EKG dan ekokardiografi. Diagnosis ISPA berdasarkan anamnesis dan pemeriksaan fisik. Dilakukan kunjungan rumah tiap bulan pada pasien untuk mengevaluasi episode dan lamanya ISPA. Kriteria inklusi tidak menderita kelainan bawaan yang lain (misalnya bibir sumbing), berdomisili di kota Manado dan mendapat persetujuan dari orang tua/wali. Analisis statistik menggunakan analisis deskriptif, regresi linear sederhana dan multipel.

Hasil. Terdapat perbedaan episode dan lamanya ISPA antara PJB non sianotik dan PJB sianotik $(\mathrm{p}<0,001)$. Terdapat hubungan antara episode ISPA dengan umur dan status gizi $(p<0,001)$. Terdapat hubungan antara lamanya ISPA dengan tipe PJB $(p<0,01)$.

Kesimpulan. Episode ISPA pada pasien PJB lebih sering dibandingkan dengan anak normal. Episode ISPA pada PJB sianotik lebih sering dibandingkan PJB non sianotik. Pasien PJB sianotik apabila mengalami ISPA lebih lama dibanding PJB non sianotik. Umur dan status gizi sangat berhubungan dengan episode ISPA pada anak-anak dengan PJB.

Kata kunci: ISPA, penyakit jantung bawaan

\footnotetext{
Alamat korespondensi:

Dr. Rocky Wilar, SpA, Prof. DR. Dr. J. M. Wantania Sp.A (K),. Bagian Ilmu Kesehatan Anak. Fakultas Kedokteran Universitas Sam Ratulangi / RSU Prof. Dr. R.D.Kandou Manado Jl. Raya Tanawangko 95115 Sulawesi Utara, PO Box 66 Telp. (0431) 821652, Fax (0431) 859091 Email: josug69@yahoo.com; ikarsup@telkom.net
}

(1) ngamatan menunjukkan bahwa pasien PJB makin bertambah jumlahnya dan menempati posisi terbanyak diantara penyakit jantung pada bayi dan anak-anak. Setiap jenis PJB membawa dampak yang berbeda satu sama lain baik perjalanan klinis, komplikasi ataupun pendekatan bedah. ${ }^{1-4}$ Gangguan hemodinamik akibat kelainan jantung memberikan gejala yang menggambarkan derajat 
kelainan, dari yang asimtomatis sampai gagal jantung yang berat disertai gagal tumbuh. Derajat gangguan pertumbuhan, sianotik, berkurangnya toleransi latihan, infeksi saluran napas berulang serta komplikasi neurologis dapat merupakan petunjuk beratnya kelainan.,

Infeksi berulang sering merupakan masalah besar pada pasien PJB. Lingkaran antara infeksi dan malnutrisi jelas berdampak negatif pada pertumbuhan anak dengan PJB. Pasien PJB yang mengalami infeksi akut misalnya infeksi saluran pernapasan akan menyebabkan anoreksia, malabsorbsi dan gangguan metabolisme. Anoreksia dan sesak napas dapat menyebabkan problem makan pada anak-anak. Pada anak tidak cukupnya konsumsi makanan akan menyebabkan turunnya berat badan, pertumbuhan terhambat, menurunnya imunitas dan kerusakan mukosa. Perubahan dalam sirkulasi paru menyebabkan perubahan sistem pernapasan disertai penurunan kekebalan seluler setempat yang memudahkan pasien terserang infeksi saluran pernapasan..$^{4,7,8}$

Di Indonesia, ISPA merupakan penyakit yang sangat sering diderita anak-anak; 90\% di antara ISPA pada anak merupakan infeksi saluran pernapasan atas akut. Banyak faktor risiko yang berhubungan dengan terjadinya ISPA pada anak-anak diantaranya umur, jenis kelamin, gizi, jumlah keluarga, pendidikan orang tua, pekerjaan orang tua, sosial ekonomi, lingkungan dan fasilitas kesehatan yang tersedia. ${ }^{9-12}$

\section{Metoda}

Penelitian ini adalah studi kohort berupa tinjauan atau observasi secara longitudinal (prospektif) yang dilakukan selama bulan November 2004 sampai Juni 2005. Subyek penelitian adalah semua anak yang berusia 6 bulan sampai 12 tahun yang datang berobat di poliklinik bayi/anak dan ruang rawat inap anak, dokter spesialis anak dan dokter spesialis penyakit jantung yang didiagnosis dengan PJB berdasarkan anamnesis, pemeriksaan fisik, radiologis, elektrokardiografi dan ekokardiografi. Kriteria inklusi adalah tidak menderita kelainan bawaan yang lain (kelainan bawaan yang menyertai PJB sehingga sulit menentukan hubungannya dengan infeksi saluran pernapasan), subyek berdomisili di Kota Manado, mendapat persetujuan dari orang tua/ wali agar anaknya dapat diikutsertakan dalam penelitian. Kriteria eksklusi menderita kelainan bawaan yang lain (misalnya bibir sumbing), menderita penyakit kronis (misalnya tuberkulosis paru, gagal jantung, asma). Subyek akan mengalami putus uji (drop out) apabila ditemukan penyakit kronis saat periode evaluasi, penderita pindah tempat tinggal dan tak bisa dilakukan kontrol/evaluasi. Prosedur pengumpulan data dilakukan dengan wawancara langsung kepada orang tua/wali untuk mengisi kuisioner yang telah disediakan, melakukan pemeriksaan lengkap pada pasien (anamnesis, pemeriksaan fisik, radiologis, elektrokardiografi dan ekokardiografi) untuk menentukan jenis kelainan jantungnya, kunjungan rumah setiap bulan oleh peneliti untuk mendata episode dan lamanya menderita ISPA, evaluaasi dilakukan selama 5 bulan. Masing-masing orang tua diberikan lembaran isian untuk mencatat bila anaknya sakit (mencatat waktu, jenis, lamanya, keluhan sakit). Analisis data digunakan teknik analisis deskriptif untuk semua variabel, uji-t digunakan untuk menguji perbedaan episode ISPA antara PJB asianotik dan PJB sianotik, uji Mann-Whitney U untuk menguji perbedaan lama ISPA antara PJB asianotik dan PJB sianotik, analisis regresi linear multipel yang dilanjutkan dengan prosedur stepwise digunakan untuk menganalisis hubungan antara beberapa variabel bebas dan variabel tergantung.

\section{Hasil}

Selama periode penelitian 10 Nopember 2004 sampai 10 Juni 2005, telah didapatkan 47 pasien anak yang memenuhi kriteria inklusi. Karakteristik subyek yang dapat menyelesaikan penelitian secara lengkap tertera pada Tabel 1 dan 2.

Diagnosis penyakit jantung bawaan terbesar adalah teknologi Fallot (TF) dan terkecil ductus arterious persistent (DAP) dan defect septum ventricle + pulmonal stenosis (DSV + PS) (berat). Data tertera pada Tabel 3.

Tipe PJB non sianosis terdapat pada 29 pasien dan 18 pasien menderita PJB sianotik. Pada penelitian ini pengamatan episode dan lamanya ISPA pada pasien PJB dilakukan selama 5 bulan. Pada Tabel 4 tertera rerata episode ISPA pada anak PJB nonsianotik 3,97 kali/5 bulan sedangkan pada PJB sianotik 6,59 kali/5 bulan. Rerata lamanya mengalami ISPA pada PJB nonsianotik 3,5 hari dan pada PJB sianotik 4,1 hari. Secara statistik didapatkan adanya perbedaan yang bermakna antara PJB asianotik dan PJB sianotik dalam hal episode dan lamanya ISPA ( $\mathrm{p}<0,001)$. 
Tabel 1. Distribusi pasien berdasarkan jenis kelamin, umur, status gizi dan jumlah anggota keluarga

\begin{tabular}{lc}
\hline \multicolumn{1}{c}{ Karakteristik $(\mathbf{n}=47)$} & Jumlah \\
\hline Jenis kelamin & \\
Laki-laki & 29 \\
Perempuan & 18 \\
U m u r (tahun) & \\
$\leq 5$ & 26 \\
$6-10$ & 14 \\
$\geq 11$ & 7 \\
Status Gizi & \\
Buruk & 10 \\
Kurang & 24 \\
Baik & 13 \\
Jumlah anggota keluarga (orang) & \\
$\quad \leq 5$ & 23 \\
6-10 & 23 \\
$\geq 11$ & 1 \\
\hline
\end{tabular}

Tabel 2. Distribusi pasien berdasarkan pekerjaan, lama pendidikan ayah dan ibu

\begin{tabular}{lcc}
\hline Pekerjaan $(\mathbf{n}=47)$ & Ayah & Ibu \\
\hline PNS/TNI/Polri & 10 & 7 \\
Wiraswasta & 7 & 1 \\
Karyawan & 15 & 3 \\
Buruh/tani/nelayan & 15 & 1 \\
IRT/tidak bekerja & - & 35 \\
Lama pendidikan (tahun) & & \\
$\leq 6$ & 6 & 8 \\
$7-9$ & 9 & 6 \\
$10-12$ & 25 & 24 \\
$\geq 13$ & 7 & 9 \\
\hline
\end{tabular}

Dari 47 pasien yang diteliti dan dianalisis dengan regresi multipel, didapatkan hubungan secara parsial yang bermakna antara episode ISPA dengan umur, status
Tabel 3. Distribusi pasien berdasarkan diagnosis dan tipe PJB

\begin{tabular}{lc}
\hline \multicolumn{1}{c}{ Diagnosis (n=47) } & Jumlah \\
\hline DSA (Defek septum atrium) & 9 \\
DSV (Defek septum ventrikeld) & 6 \\
SP (Stenosis pulmonal) & 6 \\
DSV + SP (ringan/ringan-sedang) & 7 \\
DAP (Duktus arteriosus persisten) & \\
TF (Tetralogi Fallot) & 15 \\
DSV + SP (berat) & 1 \\
DSV + Situs inversus & 2 \\
Asianotik & $29(61,7 \%)$ \\
Sianotik & $18(38,3 \%)$ \\
\hline
\end{tabular}

gizi dan tipe PJB $(p<0,001)$. Sedangkan jenis kelamin, jumlah anggota keluarga, pendidikan ayah/ibu, pekerjaan ayah/ibu tidak mempunyai hubungan secara parsial dengan episode ISPA $(p>0,05)$. (Tabel 5)

Dari analisis statistik tidak didapatkan hubungan secara parsial yang bermakna antara lamanya ISPA pada anak PJB dengan umur, jenis kelamin, status gizi, jumlah anggota keluarga, pendidikan ayah/ibu, pekerjaan ayah/ ibu $(p>0,05)$. Tapi didapatkan adanya hubungan secara parsial yang bermakna antara rerata lamanya ISPA dengan tipe PJB $(p=0,001)$. (Tabel 7)

Hasil uji dengan prosedur stepwise terhadap tipe PJB, terdapat koefisien regresi (B) 0,576, t 4,284, dan p 0,000 .

\section{Diskusi}

Selama periode penelitian dari 10 Nopember 2004 sampai 10 Juni 2005 didapatkan sebanyak 47 pasien PJB. Dari hasil evaluasi didapatkan rerata episode ISPA pada PJB asianotik 3,97 kali/5 bulan (9-10 kali/tahun) dan pada PJB sianotik 6,59 kali/5 bulan (15-16 kali/

Tabel 4. Distribusi pasien berdasarkan episode dan lama ISPA

\begin{tabular}{|c|c|c|c|c|c|c|}
\hline \multirow{2}{*}{ Karakteristik } & \multicolumn{5}{|c|}{ Nilai Statistik (hari) } & \multirow[b]{2}{*}{$\mathrm{p}$} \\
\hline & Rerata & Median & SD & Minimum & Maksimum & \\
\hline \multicolumn{7}{|l|}{ Episode ISPA } \\
\hline PJB nonsianotik & 3,97 & 4,00 & 1,451 & 2 & 7 & $0,000^{*}$ \\
\hline PJB sianotik & 6,59 & 6,00 & 1,653 & 4 & 10 & \\
\hline \multicolumn{7}{|l|}{ Lama ISPA } \\
\hline PJB nonsianotik & 3,5 & 3,5 & 0,4633 & 2,9 & 4,5 & $0,000^{* *}$ \\
\hline PJB sianotik & 4,1 & 4,0 & 0,4212 & 3,2 & 4,9 & \\
\hline
\end{tabular}


Sari Pediatri, Vol. 8, No. 2, September 2006

Tabel 5. Hubungan antara episode ISPA dengan umur, jenis kelamin, status gizi, jumlah anggota keluarga, pendidikan ayah/ibu, pekerjaan ayah/ ibu dan tipe PJB

\begin{tabular}{lccc}
\hline \multicolumn{1}{c}{ Variabel } & Koefisien regresi (B) & $\mathbf{t}$ & $\mathbf{p}$ \\
\hline U m u r & $-0,196$ & $-4,654$ & 0,000 \\
Jenis kelamin & $-0,278$ & $-0,817$ & 0,419 \\
Status gizi & $-1,536$ & $-6,829$ & 0,000 \\
Jumlah anggota keluarga & $-0,061$ & $-0,816$ & 0,420 \\
Pendidikan ayah & $-0,091$ & $-1,140$ & 0,262 \\
Pendidikan ibu & $-0,009$ & $-0,122$ & 0,904 \\
Pekerjaan ayah & $-0,423$ & $-1,115$ & 0,272 \\
Pekerjaan ibu & $-0,643$ & $-1,747$ & 0,089 \\
Tipe PJB & 1,679 & 4,922 & 0,000 \\
\hline
\end{tabular}

Variabel dependen : episode ISPA

Tabel 6. Hasil uji dengan prosedur stepwise terhadap status gizi, umur dan pekerjaan ibu

\begin{tabular}{lcrc}
\hline \multicolumn{1}{c}{ Variabel } & Koefisien regresi $(\mathbf{B})$ & $\mathbf{t}$ & $\mathbf{p}$ \\
\hline Tipe PJB & 1,848 & 5,942 & 0,000 \\
Status gizi & $-1,437$ & $-6,813$ & 0,000 \\
U m u r & $-0,178$ & $-4,684$ & 0,000 \\
Pekerjaan ibu & $-0,686$ & $-2,071$ & 0,045 \\
\hline
\end{tabular}

Tabel 7. Hubungan antara rerata lamanya ISPA dengan umur, jenis kelamin, status gizi, jumlah anggota keluarga, pendidikan ayah/ibu, pekerjaan ayah/ibu dan tipe PJB

\begin{tabular}{lcrc}
\hline \multicolumn{1}{c}{ Variabel } & Koefisien regresi (B) & $\mathbf{t}$ & $\mathbf{p}$ \\
\hline U m u r & $-0,018$ & $-0,962$ & 0,342 \\
Jenis kelamin & 0,178 & 1,149 & 0,258 \\
Status gizi & $-0,061$ & $-0,595$ & 0,555 \\
Jumlah anggota keluarga & 0,024 & 0,691 & 0,494 \\
Pendidikan ayah & $-0,011$ & $-0,292$ & 0,772 \\
Pendidikan ibu & 0,011 & 0,320 & 0,751 \\
Pekerjaan ayah & $-0,196$ & $-1,132$ & 0,265 \\
Pekerjaan ibu & $-0,071$ & $-0,423$ & 0,675 \\
Tipe PJB & 0,580 & 3,731 & 0,001 \\
\hline
\end{tabular}

tahun). Didapatkan episode terendah pada PJB asianotik $2 \mathrm{kali} / 5$ bulan dan tertinggi $7 \mathrm{kali} / 5$ bulan sedangkan pada PJB sianotik terendah $4 \mathrm{kali} / 5$ bulan dan tertinggi $10 \mathrm{kali} / 5$ bulan.

Hasil evaluasi tersebut didapatkan bahwa episode ISPA pada anak PJB lebih tinggi dibandingkan dengan anak yang normal terutama pada PJB tipe sianotik ( $p$ $<0,001)$. Dalam kepustakaan dikatakan bahwa anakanak normal umur 1-6 tahun akan mengalami infeksi saluran pernapasan 7-9 kali/tahun. Insiden tertinggi terdapat pada umur 3 tahun pertama kehidupan dan jumlahnya tidak berubah hingga sekitar 4-6 kali/tahun pada usia 8-10 tahun. ${ }^{11,13,14}$

Pada PJB sianotik dengan pirau kanan ke kiri sering ditemukan hipoksemia karena derajat stenosis pulmonalnya bertambah setiap waktu sehingga meningkatkan risiko serangan hipersianotik. Pasien juga akan mengalami penurunan volume paru, hipoplasia jalan napas serta gangguan ventilasi perfusi. Semuanya ini akan menyebabkan kerusakan mukosa saluran napas, gangguan imunitas dan pada akhirnya meningkatkan risiko infeksi saluran pernapasan. ${ }^{15,16-18}$

Infeksi saluran pernapasan sering dialami pada 3 tahun pertama kehidupan, khususnya pada tahun pertama. Hal ini kemungkinan berhubungan dengan status imunitas dan ukuran jalan napas yang kecil pada anak-anak yang lebih muda. ${ }^{13,16}$ Setelah usia 3 tahun insiden infeksi saluran pernapasan akan menurun.

Penelitian oleh Duppenthaler $\mathrm{dkk}^{19}$ serta Boyce $\mathrm{dkk}^{20}$ mendapatkan bahwa anak PJB mempunyai risiko tinggi untuk mengalami infeksi respiratory syncytial virus (RSV) terutama pada tahun pertama kehidupannya. Gangguan gizi juga akan mempengaruhi sistem imunitas, saluran napas dan sistem organ yang lain sehingga selanjutnya meningkatkan risiko infeksi dan memperlambat penyembuhan penyakit. $^{21,22}$

Dari hasil evaluasi didapatkan median lama ISPA pada PJB nonsianotik 3,5 hari dan pada PJB sianotik 4 hari. Lama ISPA terendah pada PJB nonsianotik 2,9 hari dan tertinggi 4,5 hari. Sedangkan pada PJB sianotik lama ISPA terendah 3,2 hari dan tertinggi 4,9 hari. Walaupun secara statistik terdapat perbedaan antara lama ISPA pada PJB nonsianotik dibandingkan dengan PJB sianotik $(p<0,001)$ tetapi secara klinik tidak ada perbedaan (3,5 hari vs 4 hari).

Anak PJB seringkali mengalami infeksi saluran napas dan bila terkena lebih lama sembuh dibanding anak yang normal, gagal jantung memperburuk keadaan tersebut. Faktor yang dianggap menyebabkan lamanya infeksi tersebut adalah adanya kompresi bronkus besar oleh atrium kiri atau arteri pulmonalis yang membesar akibat hipertensi pulmonal, terjadinya atelektasis atau edema paru akibat hiperperfusi paru, hipoksemia pulmonal dan hipoplasia jalan napas. ${ }^{7,23-25}$ 


\section{Daftar Pustaka}

1. Sastroasmoro S, Madiyono B. Epidemiologi dan etiologi penyakit jantung bawaan. Dalam : Sastroasmoro S, Madiyono B, penyunting. Buku ajar Kardiologi Anak. Jakarta : Ikatan Dokter Anak Indonesia, 1994: $165-72$.

2. Oemar K. Defek septum ventrikular dan stenosis pulmonal pada penyakit jantung kongenital. Maj Kedok Indon 1994;44:51-8.

3. Sastroasmoro S, Suwarniaty R. Deteksi dini dan saat rujukan neonatus dengan penyakit jantung bawaan kritis. Dalam : Aditiawati, Bahrun D, Herman E, Prambudi R, penyunting. Naskah lengkap Simposium Nefrologi VII dan Simposium Kardiologi V, Palembang 23-24 Juni 2001. Ikatan Dokter Anak Indonesia, 2001.h. 45-55.

4. Madiyono B. Tatalaksana masalah kardiologi anak : Bagian I. Klasifikasi dan tatalaksana penyakit jantung bawaan. Sari Pediatri 1994;2:57-65.

5. Sastroasmoro S. Sampurno SI. Anamnesis dan pemeriksaan fisik. Dalam : Sastroasmoro S, Madiyono B, penyunting. Buku ajar Kardiologi Anak. Jakarta : Ikatan Dokter Anak Indonesia, 1994.h. 1-26.

6. Soeroso S, Sastrosoebroto H. Penyakit jantung bawaan non sianotik. Dalam : Sastroasmoro S, Madiyono B, eds. Buku Ajar Kardiologi Anak. Jakarta : Ikatan Dokter Anak Indonesia, 1994 : 1991-233.

7. Sutaryo TS, Sudjarwo SR. Aspek pediatri sosial penyakit jantung bawaan. Dalam : Madiyono B, Oesman IN, Sastroasmoro S, Amdani SK, Putra ST, penyunting. Diagnosis dan penatalaksanaan penyakit jantung bawaan yang dapat dikoreksi. Naskah Lengkap Pendidikan Tambahan Berkala IKA ke XI FK-UI Jakarta, 1985. h.120-9.

8. Poskitt EME. Failure to thrive in congenital heart disease. Arch Dis Child 1993:158-60.

9. Depkes RI Ditjen PPM \& PLP. Infeksi saluran pernapasan akut (ISPA). Jakarta, 1989.

10. Depkes RI Ditjen PPM \& PLP. Pedoman pemberantasan penyakit infeksi saluran pernapasan akut (ISPA). Jakarta, 1993.

11. Zain MS. Infeksi saluran pernapasan akut pada anak. Maj Kedok Indon 1994; 44: 474-9.
12. Depkes RI Ditjen PPM \& PLP. Prosiding Lokakarya Infeksi Saluran Pernapasan Akut (ISPA) II. Ciloto, 1988.

13. Phelan PD, Landau LL, Alinsky A. Respiratory illness in children; edisi ke 3. Melbourne : Blackwell Scientific Publication, 1990.h. 25-38.

14. Goh DYT, Shek LPC, Wah LB. Acute respiratory tract infections in children: outpatient management. Bull National University Hospital 1999.h.1-9.

15. Bancalari E, Jesse MJ, Gelband H. Lung mechanics in congenital heart disease with increased and decreased pulmonary blood flow. J Pediatr 1977; 90:192-5.

16. Cabalka AK. Physiologic risk factor for respiratory viral infections and immunoprophylaxis for respiratory syncytial virus in young children with congenital heart disease. Pediatr Infect Dis J 2004 ; 23:41-5.

17. Berger RMF. Possibilities and impossibilities in the evaluation of pulmonary vascular disease in congenital heart disease. Eur Heart J 2000; 21:17-27.

18. Hoffman JI, Rudolph AM, Heymann MA. Pulmonary vascular disease with congenital heart lesions : pathologic features and causes. Circulation 1981; 64:873-7.

19. Duppenthaler A, Amman RA, Hrisoho MG. Low incidence of respiratory syncytial virus hospitalisations in hemodynamically significant congenital heart disease. Arch Dis Child 2004;89:961-5.

20. Boyce TG, Mellen BG, Mitchel EF. Rates of hospitalization for respiratory syncytial virus infection among children in Medicaid. J Pediatr 2000;137:865-70.

21. Notoatmodjo S, penyunting. Ilmu kesehatan masyarakat, prinsip-prinsip dasar. Edisi pertama. Jakarta: PT. Rineka Cipta 2003.h. 14-9.

22. Chen CW, Li CY, Wang JK. Growth and development of children with congenital heart disease. J Adv Nurs 2004;47:260-9.

23. Sondheimer JM. Hamilton JR. Intestinal function in infants with severe congenital heart disease. J Pediatr 1978; 92:572-8.

24. Owayed AF, Campbell DM, Wang EEL. Underlying causes of recurrent pneumonia in children. Arch Pediatr Adolesc Med 2000; 154:190-4.

25. Moler FW, Khan AS, Meliones JN. Respiratory syncytial virus morbidity and mortality estimates in congenital heart disease patients: a recent experience. Crit Care Med 1992; 20:1406-13. 